\title{
The structuring considerations of a Ricoeurian hermeneutic employed in a reading of Proverbs 14:2
}

\author{
Author: \\ Anneke Viljoen ${ }^{1}$ \\ Affiliation: \\ ${ }^{1}$ Department of Old \\ Testament Studies, Faculty \\ of Theology, University of \\ Pretoria, South Africa \\ Correspondence to: \\ Anneke Viljoen \\ Email: \\ anchri@mweb.co.za \\ Postal address: \\ PostNet Suite 129, Private \\ Bag X504, Northway 4065, \\ South Africa \\ Dates: \\ Received: 30 Oct. 2014 \\ Accepted: 06 Apr. 2015 \\ Published: 18 June 2015 \\ How to cite this article: \\ Viljoen, A., 2015, 'The \\ structuring considerations \\ of a Ricoeurian hermeneutic \\ employed in a reading \\ of Proverbs 14:2', HTS \\ Teologiese Studies/ \\ Theological Studies 71(3), \\ Art. \#2849, 7 pages. http:// \\ dx.doi.org/10.4102/hts. \\ v71i3.2849

\section{Copyright:} \\ (C) 2015. The Authors \\ Licensee: AOSIS \\ OpenJournals. This work is \\ licensed under the Creative \\ Commons Attribution \\ License.
}

Read online:

Scan this QR

code with your

smart phone or

mobile device

to read online.
A Ricoeurian hermeneutic affords readers of the Old Testament an opportunity to access the biblical text anew as a source and norm for faith. Reese gave a convenient summarising description of Ricoeur's hermeneutical approach. Ricoeur organised his considerations around four poles, namely distanciation, objectification, projecting of a world, and appropriation. These operate as the structuring considerations of a Ricoeurian hermeneutic and were illustrated with a sample proverb (i.e. Pr 14:2) from the collection Proverbs 10:1-15:33.

\section{Alternative approaches to text interpretation?}

Alternative approaches to text interpretation have introduced an opportunity to understand the biblical text afresh (Viljoen \& Venter 2013). Brueggemann (2003:xi) notes how these developments in the interpretive perspective of Old Testament study have made a difference to the way in which the Old Testament may be accessed as a source and norm for faith. The emergence of a variety of reading strategies that stand alongside historical critical methods of text interpretation supplement scholarly, and I may add non-scholarly, hermeneutical efforts to access more of the fullness of the biblical message. This shift in hermeneutical focus can be especially helpful to pastors and lay readers of the Old Testament. This is also my main concern; to make hermeneutical apparatus available to lay readers of the Bible as well as to teachers and preachers of the Old Testament text within the interpretive community of the church. A historical critical reading of the biblical text which is at least perceived to be a highly academic enterprise may be experienced by non-scholarly readers of the Bible as a daunting task. Besides, historical critical information may be already available to pastors and lay readers in the form of introductions or commentaries, but what to make of that highly academic information might not always be easily integrated into their interaction with the biblical text in the faith life of a community of believers. ${ }^{1}$

Within this milieu of the emergence of other approaches to and methods of text interpretation, I want to explore one such an alternative approach to the biblical text: a Ricoeurian hermeneutic. ${ }^{2}$ I will survey the contributions or benefits of ${ }^{3}$ some of the philosophical foundations and the practical implementation of a Ricoeurian hermeneutic with a sample proverb, Proverbs 14:2, as a case study. Ricoeur (1981:4) understands his hermeneutical efforts to be complementary to, and not superseding ${ }^{4}$ historical critical methods. ${ }^{5}$

\section{Advantages of a Ricoeurian hermeneutic}

Maybe the greatest advantage or contribution that a Ricoeurian hermeneutic brings to the hermeneutic enterprise is its ability to be accessible to and employable by all readers of the Bible, regardless of the reader's depth of academic or scholarly knowledge. This is opposed to historical critical endeavours that, at least to church pastors and lay readers of the Scriptures, may be 1.Brueggemann (2003) states the predicament of older scholarship that was dominated by historical critical approaches.

2.I have previously made a limited exploration of a Ricoeurian hermeneutic as an alternative approach to text interpretation (cf. Viljoen \& Venter 2013).

3.Although there are critiques of Ricoeur's hermeneutical approach, due to the focus of the article, which is to make the interpretive contribution of a Ricoeurian hermeneutic available also to lay readers of the Bible, I will not afford attention here to critiquing the approach. What impels me to look favourably on Ricoeur's hermeneutical approach to texts - despite the critique levelled against it - will be set out in the next section.

4. Ricoeur (1981:4) points out that a reading based on the semiotic of texts does not stand over and against the historical-critical method of text interpretation, but that it is rather a question of another technique of text interpretation: 'What is specifically different about the semiotic study of texts is that it does not ask about the history of redaction of a text or to what setting the successive authors of their respective audience might have belonged. Instead it asks how a text functions as a text in its current state. If one identifies exegesis with the historical-critical method, the semistic as lysis of texts is not a form of exegesis'. As the specific focus of this article is the making the is the making avalable of alternative her

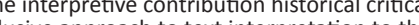
methods may make. A Ricoeurian hermeneutic is by no means to be advocated as an exclusive approach to text interpretation to the
detriment of other approaches.

5.From within the South African context this complementary approach to Old Testament and wisdom text interpretation have been operating for quite some time. Bosman (1986:14-15) advocates a complimentary approach to Old Testament text interpretation where historical and literary approaches complement each other, and Schneider (1990:61) illustrates how such a complementarity may operate in the exegetical process of a model for translating Proverbs. 
perceived to be a venture to be conducted by experts only. A Ricoeurian hermeneutic, although it has deep philosophical foundations, can be boiled down to four questions that any reader of a biblical text can ask in order to enter into a conversation with the text.

This brings me to another contribution of a Ricoeurian hermeneutic that Brueggemann alludes to in reference to alternative approaches to text interpretation. A Ricoeurian hermeneutic has the potential to make the interface between the ancient biblical text and the contemporary interpretive community 'more poignant and palpable' (Brueggemann 2003:xi). As is potentially the case with all conversations we have in life, both the dialoguing partners bring to the conversation all of themselves and it is in the encounter between the two that one may come away enriched. My aim is to contribute to creating such a space for encounter between the ancient biblical text that is by most Christians, in some way or the other, also believed to be the Word of God, and the modern day reader. ${ }^{6}$

A third contribution that a Ricoeurian hermeneutic may make is its affording an opportunity to understand faith concepts expressed in the text afresh in order to access it anew as 'a source and norm for faith' (Brueggemann 2003:xi). I will endeavour to show how such a reading of the text can be utilised to access the faith concept 'the fear of the Lord' that is expressed in the sample proverb. I will apply a Ricoeurian hermeneutic to Proverbs 14:2 in an effort to illustrate how it may unlock the invitation the proverb presents to contemporary readers of the text with regard to the fear of the Lord.

Fourthly, a Ricoeurian hermeneutic affords what I would like to call a constructive reading of the text. In a double movement Ricoeur's hermeneutic of suspicion and retrieval offers the reader apparatus to engage the text constructively as opposed to a deconstructive engagement of the text. Ricoeur's hermeneutic of suspicion opens the reader to his or her own, as well as the text's, hidden ideologies, but through a hermeneutics of retrieval affords the reader a way of moving beyond suspicion to retrieving a second naiveté that affords a constructive critical engagement of the text. ${ }^{7}$

6.1 am well aware of the complexities surrounding an understanding of the biblical text as the Word of God. For this reason I add the qualification in some way or the other. Not all readers of the biblical text have a univocal understanding of the Scriptures in this regard. Differing canons that function in different Church traditions as well as the existence of alternative texts (with the accompanying science of text criticism) adds to the complexity. For the purposes of this article which is to explore an alternative approach to text interpretation that may be helpful to both scholarly but especially also to non-scholarly readers of the Biblical text, these complexities need not be explored here. However one understands the Biblical text, I am of opinion that this approach to text interpretation is widely applicable. As one cannot approach the text without prejudices, for clarification, I will shortly state my own preunderstanding or forestructure with which I approach the text. With Brueggemann (2010:379) I want to take the text as 'scripture of the church'. Thus I engage academics for the sake of the church and want to make scholarly efforts available to the believing community who reads in the text not just the words of the author[s] or redactor[s] but read the Bible expecting to find something more that the text signals but never explains (cf. Brueggemann 2010:382). It is this something the text signals but never explains (cf. Brueggemann 2010:382). It is this something more (that I term the Word of God) that makes an inquiry into the 'imaginative connections between old textual rhetoric and contemporary life in the world" (Brueggemann 2010:383) worth exploring, as this is what makes the text normative
for the believing community.

7.Due to the focus of the article I will not elaborate here on Ricoeur's hermeneutics of suspicion and retrieval (cf. Scott-Baumann 2009).
In the process of illustrating the practical implementation of a Ricoeurian hermeneutic I will also touch on some of the philosophical foundations ${ }^{8}$ of a Ricoeurian hermeneutic in order to be able to more fully access the advantages thereof. ${ }^{9}$

Let us now turn to the practical implementation of this alternative approach to text interpretation.

\section{Four poles of a Ricoeurian hermeneutic formulated as four questions}

Reese ([1979] 1990:384-388) gives a convenient summarising description of Ricoeur's hermeneutical approach. According to him, 'Ricoeur organises his considerations around four poles' (Reese [1979] 1990:384), namely distanciation, objectification, projecting of a world, and appropriation. These operate as the structuring considerations of a Ricoeurian hermeneutic and I will formulate them into four questions that any reader of the biblical text can ask in order to access more of the fullness that the text has to offer to its readers.

\section{Distanciation: What does the text want to communicate to me - the reader - today?}

Distanciation entails being conscious of the distinctive nature of written discourse. Written texts are a distinctive kind of discourse, as differentiated from speech. Ricoeur (1974:95) points out that the relation writing-reading is dissimilar to the relation speaking-hearing. A written text is discourse without the possibility of that exchange we call dialogue or conversation in the sense of spoken language. With written literary works, Ricoeur (1974:95) says 'the discourse must speak by itself'.

Reading a text conscious of the distinctive nature of written discourse leads to the deliberate emancipation of the message of a written text from the intentional horizon of its author and initial communicative setting (Reese [1979] 1990:384). Ricoeur (1977:22) points out that writing brings into being discourse that is instantaneously independent of its author's intention. He explains that:

Thanks to writing, the world of the text can burst the world of the author. This emancipation with regard to the author has its parallel on the side of whoever receives the text. The autonomy of the text also removes this reader from the finite horizon of its original audience. (Ricoeur 1977:22)

\footnotetext{
8.1 say some of the philosophical foundations of a Ricoeurian hermeneutic, for as Sandoval (2006:6) points out 'Ricoeur's work is philosophically dense and sophisticated'. Reese ([1979] 1990:388) also remarks that the text-centred philosophical hermeneutic developed by Ricoeur is an exciting method but also a complicated one'. I am in agreement with both these authors about the applicability of a Ricoeurian hermeneutic to wisdom literature. Sandoval points out that aspects of Ricoeur's work may be instructive for studying the discourse of Proverbs (Sandoval 2006:6) and Reese ([1979] 1990:388-395) senses that Ricoeur's hermen (sic is aplicable to Old Testament wisdom literature and a whole biblical book as a literary work.

9.I also drew on these same philosophical foundations in the article I mentioned earlier (cf. Viljoen \& Venter 2013), in which I explored only the second and third poles of a Ricoeurian hermeneutic, applying it there to other sample proverbs from Proverbs 10:1-15:33 with specific reference to the fear of the Lord.
} 
Thus, the interpretive task is not limited to and does not end when the interpreter of a text is able to discern what the author's communicative intention was in the initial communicative setting, or what the text might have meant for previous readers of it. Such background information concerning the text may not be available especially to nonacademic readers of the Bible who do not always have access to it. These are indeed very helpful insights that a historical critical reading of the text may facilitate for readers, if historical critical insights are available to them.

Wallace (2000:305-306) notes that for Ricoeur written discourse enters the public domain where the encounter between a text and a reader takes place. Meaning is generated when the text's potential meanings into which the author's intentions are absorbed and the reader's interpretive construals of those meanings convene. Thus the text has a plurality of meanings which are produced through the reader's responses to the range of possibilities the text projects. Historical critical insights are especially helpful in narrowing down the range of probable readings of the text that range from more to less probable readings. It is precisely because the biblical text enters the public domain of the reader where meaning is generated on the basis of this encounter that it has the ability to continue to communicate to successive generations in ever changing and ever new circumstances to remain relevant to contemporary interpretive communities.

In our current hermeneutical enquiry this consideration will lead to a reader oriented reading strategy. Schneider (1990) aptly words it with regard to wisdom literature:

In their canonical form and their translated form, sapiential insights continue to be geared towards potential audiences, which have to be instructed, admonished and guided in the ways of Biblical wisdom by means of the text which witness to ancient sapiential insights. (p. 60)

The first pole of a Ricoeurian hermeneutic, distanciation, can then be formulated into the question: what does the text want to communicate to me, the reader, today?

This first step of a Ricoeurian hermeneutic is the dialectical opposite of the last step, namely appropriation and can only be fully explored in terms of the last step. Thus we will leave the working out of this step for the time being and will only be able to fully explore it when we have come full circle to the last step, namely appropriation.

\section{Objectification: Why is the text crafted as it is? What is the significance of the form of the discourse?}

The second pole of Ricoeur's hermeneutic, objectification, reminds the reader to be mindful of the mode of discourse of the text as a means of production (cf. Reese [1979] 1990:385386). Ricoeur (1977:15) in his hermeneutical efforts cautioned against the separation of the form and content of a discourse. The message of the text cannot be severed from its vehicle and consequently it is imperative to be conscious of the linguistic system of a text. It became apparent to him that the form in which a message is encoded and the content that the form communicates are inextricably bound together.

Alter (1985:4) also perceives the necessity of this mindfulness of the mode of discourse for the heuristic process. He observes that it is important to get some handle on the linguistic system being used in a text in order to understand what kinds of meaning, what representations of human and divine reality, are made possible by the particular rhetorical vehicle (cf. Berlin [1985] 1992:17). Thus, the linguistic system employed in a text becomes an important key to the interpretation of the text (Burden 1986:40; Loader 1986:112; Human 1999:357). This is so much so that the form can even be regarded as a means by which the writer uses the resources of literary expression available to capture a fuller understanding of the subject (Alter 1985:183-184; Burden 1986:40; Potgieter 2002:1372). The dynamics of the modes of discourse or literary genres are employed by the author as the 'means of production' (Ricoeur in Reese [1979] 1990:385). Thus, it is important to appreciate the linguistic system being used in a text, as the form of a text becomes an important key to appreciating the text (Burden 1986:40; Loader 1986:112; Human 1999:357).

Describing the poetics of the text is very helpful in grasping how the form of the text and the content coalesce to carry the significance of the discourse:

A poetics is an attempt to specify how literature 'works', how it enables us to perceive the meanings we do perceive in it ... A poetics of the text is interested in how the text is articulated, in how it comes to convey the meaning it does. (Barton 1996:205)

McKane ([1979] 1990:167) states that 'what is said' cannot be separated from 'how it is said'; the force of speech and writing arises out of a marriage of form and content, and a divorce destroys the literary creation.

Reese ([1979] 1990:391) points out that the crafting of a literary work as a work of art, is an urgent invitation to a profound life of faith and the discourse calls for a response. Consequently, the second pole of a Ricoeurian hermeneutic, ${ }^{10}$ objectification, then can be formulated into the question: why is the text crafted as it is; what is the significance of the form of the discourse?

Let me now illustrate this pole with the sample proverb:

\section{Proverbs 14:211:}

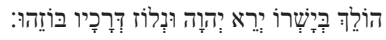

[Walker in his straightness fearer of Yahweh

but goer on his wrong ways despiser of him.]

10.Ricoeur (Reese [1979] 1990:391) defines a true author as an "artisan at work in discourse'.

11.The Hebrew text used was taken from the Biblia Hebraica Stuttgartensia. 
The antithetic structure of the proverb enables it to achieve two objectives simultaneously. Firstly, it divides the social reality into two spheres, namely:

- the fearers of Yahweh who go on straight ways

- despisers of him that go on wrong ways.

Berlin's ([1985] 1992) observation of the poetic function of parallelism is important here:

They organize, or reorganize, the world into equivalences and oppositions by their form of expression ... This was, and still is, a most effective way to give heightened awareness of the message to its receivers. (p. 140)

Secondly, the mention of walking and way plays on the metaphorical network of 'the way' often expressed in the doctrine of 'the two ways' (Sandoval 2006:131; cf. Clifford 2009:247) that is rooted in the Jewish wisdom tradition (Perdue 2000:79; cf. Betz 2008:171) and is a ground metaphor of Proverbs 1-9 (Fox 2000:128). This reinforces the choice presented to the reader either for the path of wisdom or the other path. The metaphor of 'the way', describing behaviour as a path (Fox 2000:128), is not meant to be an abstraction, but is indicated with the third person masculine singular suffix, making the intended application very practical and concrete in a person's behaviour.

With the illustration of the second pole of Ricoeur's hermeneutic completed, let us now turn our attention to the third pole.

\section{Projection of a world: What is the landscape of the world that unfolds as the text is read? How is that world?}

The projection of a symbolic world ${ }^{12}$ by the text for the reader is the consequence of the text's meaning as both sense and reference (Reese [1979] 1990:386-387). The text's meaning as sense may be distinguished through a semantic enquiry (language as lingue) or the 'what is said', according to Ricoeur, and a description of the poetics of the proverb or how it is said' as was illustrated in the previous section. In this pole of a Ricoeurian hermeneutic the meaning as reference, distinguished on the level of semiotics (language as parole) or the 'about what it is said', according to Ricoeur, will be explored. As a work of discourse, ' $[m]$ etaphorical language is able to construct a new vision of reality' (Sandoval 2006:9). The text references a symbolic-textual world that is a redescription of reality (Ricoeur 1975:87; cf. Sandoval 2006:6-10).

Ricoeur distinguishes two levels of reference (Scott [1989] 1990:48), namely a first-order reference, tied to a literal interpretation which is weakened and leads to a second order reference when the literal level is suspended (Ricoeur 1975:84; 1976:56-57; cf. Sandoval 2006:9). A text may not only

12.One of the concerns or critiques levelled against a Ricoeurian hermeneutic is the exce the text and ont the text and ontology, and if such a relationship is at all to be sought. This question cannot be explored in detail within the confines of this article, suffice it to say here that Ricoeur himself focusses on the metaphoric nature of the symbolic world that the text projects for the reader be describing reality in a literal, or empirically verifiable way, but may through the literal meaning come to a metaphorical meaning and actively be creating a symbolical world (Sandoval 2006:10).

Scott ([1989] 1990:47-48) asserts as follows: 'At this second level, narrative is a model for redescribing reality. The mimesis of fiction is not a copy of reality but its redescription'. Ricoeur (1981:51) points out that the redescriptive nature of biblical texts or operation of parabolisation is not limited to those texts that are characteristically narrative, but is also at work in other literary genres. It can thus be applied equally well to Proverbs. The redescriptive nature of biblical texts or operation of parabolisation is the operation of the biblical form of imagination (Ricoeur 1981:3-4).

Thus, Ricoeur (1976:60) describes the poetic project as 'one of destroying the world as we ordinarily take it for granted ... To bring to language modes of being that ordinary vision obscures or even represses'. Wallace $(1995: 12)$ understands that ' $t$ the aim of an imaginative text is the creative imitation of human action - even as the purpose of metaphor ... is to redescribe the actual world in terms of possibility'. The text constructs, for the reader, a symbolic-textual world (Sandoval 2006:10). The structure of the world that the text projects in front of itself for the reader reveals the structure of reality (cf. Reese [1979] 1990:387). In this way a text has the ability to 'change one's view of, or relationship to, reality' (Sandoval 2006:9).

Reese ([1979] 1990:386) describes this stage of the hermeneutical enquiry as lying 'at the heart of interpretation'. He explains that this step takes the reader out beyond the reach of first-order reference, that is, beyond direct contact with manipulable objects, into a deeper reality. According to him, the distinctive attribute of theological or religious texts are their claim to point to a unique, transcendent reference and he notes that such texts are in touch with the fullness of reality. He is in accord with Ricoeur, affirming that these texts' reference dimension gives interpretation a new depth: the interpreter aims to elucidate the world of the text that stands forth in front of the text as reality in its own right (cf. Ricoeur in Reese [1979] 1990:386).

Thus, the aim of this section of our hermeneutical enquiry is to describe the second order or transcendent reference of the text of Proverbs 14:2 in order to consider specifically its reference to the fear of the Lord; that 'deeper reality' (Reese [1979] 1990:386) that the text points to. Consequently, the third pole of a Ricoeurian hermeneutic, the projection of a world, then can be formulated into the following question: what is the landscape of the world that unfolds as the text is read; how is that world?

Let me now turn to illustrating what this pole may entail:

\section{Proverbs 14:2:}

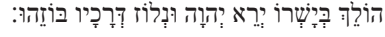

[Walker in his straightness fearer of Yahweh

but goer on his wrong ways despiser of him.] 
From the semantic analysis of this proverb, ${ }^{13}$ it became clear that the indeterminacy of the subject and predicate in both colons give expression to the proverb's conviction about the congruency between an internal disposition and outward action or behaviour of a person. This gives the reader a glance into the proverbial world in which the internal and external realities of a person are not segregated, but permeate each other, to become the motivation for moral conduct, either good or bad. This interconnectedness of the internal and external realities of moral conduct and the motivation thereof in the proverb is a reflection of how the proverb perceives the workings of moral conduct in the symbolic reality that the proverb references.

The good or bad moral behaviour of a person is here expressed with the metaphor of 'the way'; another enunciation of the proverb's view of the world as bifurcated in terms of the two courses that a person can take. Consequently, in the proverbial world a person can be found to be on either of two paths:

- in the fear of Yahweh going in straightness

- despising Yahweh going in wrong ways.

The metaphoric expression of 'the two ways', should not mislead the reader to think of moral-ethical behaviour in abstract terms. In the proverbial world, these are not abstract categories, but has very concrete manifestation in a person's conduct. This is expressed in the proverb by specifically designating his ways, person male singular. Frydrych (2002) perceives this with regard to the fear of the Lord:

The notion of good and evil are dictated by the stable nature of the proverbial world, which leads to a fairly rigid code of proper behaviour. The divine order defines what should be done, i.e., what is good, and what should not be done, i.e., what is evil. These are absolute in Proverbs and all pervasive; virtually every activity that the book is interested in can be classified under these two rubrics. Yet, it would be misleading to think of good and evil in the book as abstract theological categories; in Proverbs these are largely about what people do to other people. (p. 171)

In this symbolic reality sketched by the proverb a person's stance towards Yahweh has a significant bearing on that person's moral-ethical behaviour, with a person's moralethical behaviour congruently reinforcing the inward disposition either of fear of Yahweh or despising the Lord.

I have illustrated what an exploration of the symbolic world referenced by this proverb may entail. Let me now turn to exploring the fourth pole of a Ricoeurian hermeneutic and how this world I have described may be appropriated by the reader.

\section{Appropriation: What is the new mode of being-in-the-world that the text invites me - the reader - to?}

Appropriation, or the self-understanding arising from the text, is the last stage of a hermeneutical inquiry according

13.The semantic analysis is not included in this article but was drawn from the PhD thesis entitled 'An exploration of the symbolic world of Proverbs 10:1-15:33 with specific reference to "the fear of the Lord"' (Viljoen 2013). to a Ricoeuerian approach (Reese [1979] 1990:387-388). Through a fusion of the world of the text and the world of the reader, the reader is invited to inhabit this projected symbolic-textual world (Ricoeur 1977:25). The hermeneutical appropriation of the text or the subjective, existential moment of personal decision ensues from the semantic moment of objective meaning (Pellauer 1981:267). From my experience as a teacher and preacher of the Scriptures within a faith community, ${ }^{14}$ this pole is at the heart of the faith life of the church and of immense value in facilitating an existential moment of personal decision.

Here the discord between the regular appreciation of the task of explanation, that is to say that it demands a certain objectivity and lack of self-involvement that is supposed to characterise scientific explanation, and Ricoeur's understanding of interpretation comes into play. I will briefly present the key concepts of Ricoeur's theory of interpretation that is the basis of his re-appraisal of the hermeneutic circle and at the same time the philosophical foundation of the fourth pole of his hermeneutic.

The problem of interpretation is for Ricoeur (1974:99) connected 'to the dimension of reference understood as the power of discourse to apply to an extra-linguistic reality about which it says what it says'. But discourse has a twofold reference that both function from the level of the sentence: intentional or a reality-reference and reflective or a selfreference. In Ricoeur's (1974:99) own words, this reference is both thing-bound through its reference to an extra-linguistic reality or world and self-bound through its reference to its own speaker.

Understanding then, Verstehen, as opposed to explanation, Erklärung, is to follow the movement of the work, its dynamics from what it says to that about which it speaks. This is to follow the text's intentional reference as we have done in the previous section. A reader of the text may at the very same time also follow the reflective intention of the text.

According to Ricoeur (1974:107-108), the hermeneutical circle is still a very necessary apparatus of interpretation, but on the basis of his theory of the task of interpretation a reappraisal of the hermeneutic circle is necessary. He moved the understanding of the hermeneutic circle from a subjectivistic to an ontological level. All genuine interpretation ends in some kind of appropriation, that is, the process of making one's own what was other, but Ricoeur (1974:107) claims that the hermeneutical circle is not correctly understood when it is presented as a circle between two subjectivities, that of the reader and that of the author, and as the projection of the subjectivity of the reader in the reading itself.

That which readers of a text make their own, that which they appropriate for themselves, is not a subjectivity or the recognition of another person, but rather the horizon of the world which the text references. What follows from this is that

14.I pastor the Pinetown congregation of the Netherdutch Reformed Church of Africa. 
the role of subjectivity is not correctly described as projection. To understand oneself before or in front of the world the text projects for the reader is the opposite of projecting oneself and one's beliefs and preconception. Readers understand themselves before the text, before the world of the work, in order to let the work and its world expand the horizon of the readers' own self-understanding.

Rather than a hermeneutical surrender of the text under the command of the subject who interprets, interpretation, according to Ricoeur, is the process by which the text facilitates the discovery of new modes of being (à la Heidegger) or new forms of life (à la Wittgenstein) that affords subjects a new capacity of knowing themselves. As a result the reader is increased in their capacity of self-projection by receiving from the text a new mode of being in the world. Ricoeur (1974:106) explains: 'Beyond my situation as reader, beyond the author's situation, I offer myself to the possible ways of being-in-the-world which the text opens up and discovers for me'. This is Gadamer's notion of the fusion of horizons or horizontverschmelzung (Ricoeur 1974:106).

For Reese ([1979] 1990:386), '[t]o interpret is to explicate the sort of being-in-the-word unfolded in front of the text'. Consequently, the fourth and last pole of a Ricoeurian hermeneutic, appropriation, can then be formulated into the question: what is the new mode of being-in-the-world that the text invites me, the reader, to? How can I understand myself before the world that the text projects for me?

Let me now turn to illustrating how this pole of our hermeneutical enquiry may function. Bear in mind that my main aim and concern is to make the implications of a Ricoeurian hermeneutic available to lay readers of the Bible as well as to teachers and preachers of the Old Testament wisdom text within the interpretive community of the church. Hildebrandt (2005:61-62) proposes that the power and potential of the collected proverb can be unleashed in the particular story of the contemporary individual to call for a total engagement in the choices of the moment, but set these within a context of the Other (both human and divine) thereby establishing the context for significance and meaning of the choices made by each individual ' $\mathrm{I}$ ':

\section{Proverbs 14:2:}

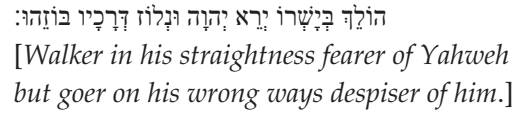

Through the indeterminacy of the subject and predicate the proverb attests to the interconnectedness in the symbolic world that the proverb projects for the reader of the external reality of a person's moral-ethical conduct and the internal reality of her or his bearing towards Yahweh either in the fear or despising of Yahweh. These cannot be segregated and instead permeate each other to become the motivation of the path a person chooses; a metaphor for the life choices that a person makes. In this way the proverb urges the contemporary reader to reflect on the congruent relationship between the internal and external realities of his or her own life.

This reality presented by the proverb through the rhetorical force of the metaphor of the straight or crooked way confronts the reader with a choice either for good moral-ethical behaviour or for bad. The choice one makes in outward conduct both reflects, as well as being motivation for, inward reality and vice versa. The proverb calls the reader to a personal decision by inviting her or him into a relationship with God that is characterised by the fear of Yahweh. The response to the invitation, according to the proverb, divides the human world into two distinct categories, namely the righteous-wise that fear the Lord and wicked-fools that do not. When this redescribed view of reality is embraced by the reader it calls the contemporary reader to an existential moment of personal decision.

This brings us back to the question we posed at the beginning of our enquiry that may be answered by readers for themselves: what does the text want to communicate to me, the reader, today? And so we have come full circle through all four poles of a Ricoeurian hermeneutic.

\section{Conclusion}

Johnson (1998) writes as follows:

If Scripture is ever again to be a living source for theology, those who practice theology must become less preoccupied with the world that produced Scripture and learn again how to live in the world Scripture produces. (p. 165)

Through its power to disclose a symbolic world the proverb presents the reader with an alternative 'model of apprenticeship' to the God that is identified in the text (Wallace 2000:304-305), and consequently an alternative mode of being-in-the-world unfolds in front of the text (Ricoeur 1977:29-30) that orients the practical actions of the reader. By illustrating how a Ricoeurian hermeneutic, as an alternative reading strategy, may function I have shown how it may contribute to accessing more of the fullness that the text has to offer. I have also shown how a Ricoeurian hermeneutic affords an opportunity to understand the concept of 'the fear of the Lord' expressed in the text afresh. My hope is that a Ricoeurian hermeneutic may contribute to accessing the Scriptures anew as a source and norm for faith not only for academic readers of the biblical text, but also for non-scholarly readers of the Bible and Old Testament wisdom literature. It is my conviction that the proposed reading strategy is a most productive effort that may add value to contemporary research of ancient Near Eastern Wisdom Literature in South Africa.

\section{Acknowledgements Competing interests}

The author declares that she has no financial or personal relationships which may have inappropriately influenced her in writing this article. 


\section{References}

Alter, R., 1985, The art of biblical poetry, Basic Books Inc., New York, NY.

Barton, J., 1996, Reading the Old Testament: Method in biblical study, Westminster John Knox Press, Louisville, KY.

Berlin, A., [1985] 1992, The dynamics of biblical parallelism, Indiana University Press, Bloomington, IN.

Betz, H.D., 2008, Religion past and present, Brill, Leiden.

Bosman, H.L., 1986, 'Die ontstaan en verstaan van die Ou Testament', in F.E. Deist \& W.S. Vorster (reds.), Woorde wat ver kom, bl. 1-15, Tafelberg Uitgewers, Kaapstad.

Brueggemann, W., 2003, An introduction to the Old Testament: The canon and Christian imagination, Westminster John Knox Press, Louisville, KY.

Brueggemann, W., 2010, 'Sometimes wave, sometimes particle', Currents in Biblical Research 8(3), 376-385, viewed 21 March 2015, from http://cbi.sagepub.com/

Burden, J.J., 1986, 'Poëtiese tekste', in F.E. Deist \& W.S. Vorster (reds.), Woorde wat ver kom, bl. 37-68, Tafelberg Uitgewers, Kaapstad.

Clifford, R.J., 2009, 'Reading Proverbs 10-22', Interpretation 63, viewed 08 June 2012 from http://int.sagepub.com/content/63/3/242

Fox, M.V., 2000, Proverbs 1-9: A new translation with introduction and commentary: Volume 18, Doubleday, New York, NY

Frydrych, T., 2002, Living under the sun: Examination of Proverbs and Coheleth, Brill, Leiden.

Hildebrandt, T., 2005, 'The proverb: An interdisciplinary approach to a biblical genre', viewed 13 November 2012, from http://0-faculty.gordon.edu.innopac.up.ac. za/hu/bi/Ted Hildebrandt/OTeSources/20-Proverbs/Text/Articles/HildebrandtProverb-Genre-2005.pdf

Human, D.J., 1999, 'Die literêr-historiese lees van 'n teks', Skrif en Kerk 20(2), 354-368.

Johnson, L.T., 1998, 'Imagining the world Scripture imagines', Modern Theology 14(2), 165-180.

Loader, J.A., 1986, 'Tekste met ' $\mathrm{n}$ wysheidsperspektief', in F.E. Deist \& W.S. Vorste (reds.), Woorde wat ver kom, bl. 103-122, Tafelberg Uitgewers, Kaapstad.

McKane, W., [1979] 1990, 'Functions of language and objectives of discourse according to Proverbs 10-30', in M. Gilbert (ed.), La sagesse de l'Ancien Testament, pp. 166-185, Leuven University Press, Leuven.

Pellauer, D., 1981, 'Paul Ricoeur on the specificity of Religious language', The Journal of Religion 61(3), 264-284. http://dx.doi.org/10.1086/486871
Perdue, L.G., 2000, Proverbs. Interpretation: A Bible commentary for teaching and preaching, John Knox Press, Louisville, KY

Potgieter, J.H., 2002, 'The (poetic) rhetoric of wisdom in Proverbs 3:1-12', HTS Teologiese Studies/Theological Studies 58(4), 1357-1374. http://dx.doi. org/10.4102/hts.v58i4.714

Reese, J.M., [1979] 1990, 'Can Paul Ricoeur's method contribute to interpreting the book of Wisdom?', in M. Gilbert (ed.), La sagesse de l'Ancien Testament, pp. 384-396, Leuven University Press, Leuven.

Ricoeur, P., 1974, 'Metaphor and the main problem of hermeneutics', New Literary History 6(1), 95-110, viewed 26 August 2014, from http://www.jstor.org/ stable/468343

Ricoeur, P., 1975, 'Biblical hermeneutics', Semeia 4, 29-148.

Ricoeur, P., 1976, Interpretation theory: Discourse and the surplus of meaning, Texas Christian University Press, Fort Worth, TX.

Ricoeur, P., 1977, 'Toward a hermeneutic of the idea of revelation', Harvard Theological Review 70, 1-37.

Ricoeur, P., 1981, 'The Bible and the imagination', in H.D. Betz (ed.), The Bible as a document of the university, pp. 49-75, Scholars Press, California, viewed 28 February 2012, from http://www.fondsricoeur.fr/photo/Ricoeur\%20\%20The\%20 Bible\%20and\%20the\%20 Imagination.pdf

Sandoval, T.J., 2006, The discourse of wealth and poverty in the book of Proverbs, Brill, Leiden.

Schneider, T.R., 1990, 'The sharpening of wisdom: Old Testament proverbs in translation', D.Th thesis, Dept. of Theology, University of South Africa.

Scott, B.B., [1989] 1990, Hear then the parables: A commentary on the parables of Jesus, Fortress Press, Minneapolis, MN.

Scott-Baumann, A., 2009, Ricoeur and the hermeneutics of suspicion, Continuum, London.

Viljoen, A. \& Venter, P.M., 2013, 'An exploration of the symbolic world of Proverbs 10:1-15:33 with specific reference to "the fear of the Lord"', HTS Teologiese Studies/Theological Studies 69(1), Art. \#2008, 6 pages. http://dx.doi.org/10.4102/ hts.v69i1.2008

Viljoen, A., 2013, 'An exploration of the symbolic world of Proverbs 10:1-15:33 with specific reference to "the fear of the Lord", PhD thesis, Dept. of Theology, University of Pretoria.

Wallace, M.I., 1995, 'Introduction', in M.I. Wallace (ed.), Figuring the sacred: Religion, narrative and imagination, transl. D. Pellauer, pp. 1-35, Fortress Press, Religion, narrative and imagination

Wallace, M.I. 2000 'From phenomenology to Scripture? Paul Ricoeur's hermeneutical philosophy of religion', Modern theology 16(3), 301-313. http://dx.doi. org/10.1111/1468-0025.00129 